\title{
The problem-based learning e-module of planes using Kvisoft Flipbook Maker for elementary school students
}

\author{
Dyah Triwahyuningtyas *, Ayu Setyo Ningtyas, Sri Rahayu \\ Universitas Kanjuruhan Malang. Jalan S. Supriadi No.48, Kota Malang, Jawa Timur 65148, Indonesia \\ * Corresponding Author. E-mail: dyahtriwahyu@unikama.ac.id
}

Received: 13 September 2020; Revised: 15 September 2020; Accepted: 25 September 2020

\begin{abstract}
The conduct of the present study is encouraged by the needs to afford the teaching materials in the form of electronic learning module or e-module that can be combined with the problem-based learning approach in order to expand the students' insights in and draw the students' interest toward Mathematics. These needs should be afforded because the present teaching materials used in the learning process are still conventional and, consequently, the students become easily bored. Departing from this elaboration, the objective of the present study is to develop the teaching materials, especially in the subject "Simple Planes" in the Third Grade, and to measure the validity, the practicality, and the effectiveness of the media that have been developed. In conducting the study, the ADDIE model, standing for Analysis, Design, Development, Implementation, and Evaluation, had been adopted and the data were gathered by means of validation sheet and response questionnaire. After the data had been gathered, the data were analysed by using the qualitative and the quantitative data analysis technique. The results of the study show that the problem-based learning (PBL)-based Mathematics e-module for the theme "Simple Planes" using the Kvisfot Flipbook Maker that has been developed is already valid with the mean score $85.82 \%$. At the same time, the results of the response category show that the problem-based learning (PBL)-based Mathematics e-module for the theme "Simple Planes" using the KVISFOT Flipbook Maker that has been developed is already good with the mean score 3.78. Furthermore, the mean score from the effectiveness test using the evaluation test for the Third-Grade students is 90.47 . Therefore, it can be concluded that the e-module is able to improve the students' learning motivation so that the learning process can proceed fluently.
\end{abstract}

Keyword: E-module, problem-based learning (PBL), KVISFOT Flipbook Maker

How to Cite: Triwahyuningtyas, D., Ningtyas, A., \& Rahayu, S. (2020). The problem-based learning e-module of planes using Kvisoft Flipbook Maker for elementary school students. Jurnal Prima Edukasia, 8(2), 199-208. doi:https://doi.org/10.21831/jpe.v8i2.34446

\section{Introduction}

The use of the technology in the present era has been expanding to the domain of education. The increasing global demand requires education to always adjust itself to the technological development in order to improve the education and the statement is mainly related to the use of the technology for the domain of education especially in the educational process (Budiman, 2017). Through education, the present era is expected to shape new individuals with the competence in their respective domain so that there will be alignment between the knowledge and the technology (Safitri, 2017; Setiawan et al., 2019). At the same time, the development of technology can also be benefitted for the learning process in the elementary school degree such as the learning process of Mathematics. The learning process in Mathematics is able to improve the students' capacity in performing logical, analytical, systematic, critical, and creative thinking with good cooperation capability (Haeruman et al., 2017). However, the students still encounter the difficulties in learning Mathematics. Specific to the context of the elementary school degree, the students still deal with so many difficulties because they are in the pre-operational concrete thinking stage. In the pre-operational concrete thinking stage, the students still need to be provided with the learning materials that support the learning process in order to facilitate their understanding because the students' thinking skills are still related to the concrete matter; therefore, the students will have difficulties when they are asked to draw complex conclusions (Suwardi et al., 2016). In order to overcome these difficulties, the appropriate learning materials are of high necessity and these learning 
Jurnal Prima Edukasia, 8 (2), 2020 - 200

Dyah Triwahyuningtyas, Ayu Setyo Ningtyas, Sri Rahayu

materials can be developed by using the well-designed lesson plans so that the learning objectives can be achieved well (Irma et al., 2019). The use of technology-based teaching materials can facilitate the delivery of the learning process and can also make the overall learning process interesting. This idea is very important to pursue because the use of textbook in a classroom can be very boring for the students because of the absence of the interactive teaching materials that can improve the students' learning enthusiasm (Divayana et al., 2019). For the teachers, the use of such learning materials in the teachinglearning activities offer another advantage such as being the reference in the delivery of the learning materials (Hutama, 2016). In addition, these teaching materials can also be implemented in the mathematical learning process, which has been considered still being complex. In order to draw more interest from the students, the mathematical learning materials can be designed by using the electronic media.

Based on the results of the field study, the teaching materials that have been used in the learning process, especially in the learning process of Mathematics, are the printed textbooks namely the student book, the teacher book, and the student worksheet that contains learning materials and test items. The weakness of these printed textbooks is that the textbooks are only available in hardcopies and, therefore, these textbooks cannot be benefitted electronically and demands huge amount of papers within the manufacture, which can be very detrimental for the environment (Anwas, 2014). In addition, the learning materials and the test items in these textbooks lack of the development toward the students' critical thinking skills and even toward the process of understanding the learning materials. Moreover, the learning materials that have been presented are less associated to the daily life context of the students. As a result, Mathematics tend to be boring and difficult to understand. The situation becomes worse because the language and the illustration that have been used are not communicative and interactive and, consequently, the message of the learning materials are less grasped by the students. Under such conditions of learning materials, the use of these textbooks demand supplementary teaching materials in order to achieve the student competencies (Supriadi, 2015). On the contrary, the results of the field study also show that the students from the Third Grade have been supplied with the LCD and the sound system as part of their learning materials. Looking at these findings, it is suggested that the learning process of Mathematics should benefit the display tools that are able to put the abstract matters into concrete (Suwardi et al., 2016). Then, in order to overcome the problems that have been found, interesting learning materials should be developed in the form of electronic-based learning module. The learning process by using the electronic-based learning module certainly displays the higher value in comparison to the ordinary textbooks (Supriadi, 2015).

In order to adjust to the electronical development, teachers should prepare learning sources and learning media that suit into the students' interest so that the students can focus their attention to the learning process and, at the same time, the teachers can diminish the sense of boredom among the students (Sriwahyuni et al., 2019). Therefore, the development of the printed module should be combined with the development of the electronic media popularly known as e-module (Munthe et al., 2019). Emodule is one of the learning materials that have been systematically designed based on the governing curriculum, packaged in a certain unit of time, and displayed and run over the gadget such as Androidbased smartphone, computer, and notebook PC or laptop (Santosa et al., 2017). The use of e-module as the materials in the learning process can improve the students' creativity and critical thinking skills and also create the active, effective, innovative, and enjoyable classroom (Winatha \& Abubakar, 2018). Within the e-module, the students are able to understand the learning materials and solve the problems through enjoyable ways.

With regards to the above explanation, Geometry is one of the branches in Mathematics that deals with the shape of a plane and a room (Nur'aini et al., 2017). Then, one of the aspects that have been studied by this branch is the simple planes. The simple planes will be easier to study if the materials are associated with the context of the students' daily life which have been designed interestingly so that the students will not be bored. Simple planes, or planes in general, are one of the learning materials that should be mastered by the Third-Grade students. Planes refer to the illustration of the concrete objects in the daily life; consequently, the discussions of these planes are not apart from the important examples (Rohman et al., 2017). Thus, the materials in the e-module should be designed as interesting as possible by adding the illustrations that catch the students' attention and the test items that exercise the students' critical thinking skills. Therefore, the design of the e-module demands the assistance from an application that is able to modify the typical module into the electronic module. In this case, designing such e- 
Jurnal Prima Edukasia, 8 (2), 2020 - 201

Dyah Triwahyuningtyas, Ayu Setyo Ningtyas, Sri Rahayu

module is easy because the design activities have been supported by numerous e-module generator applications.

One of the software that can be used for generating the e-module is the Kvisoft Flipbook Maker. Kvisoft Flipbook Maker is used as the application for generating the Mathematics e-module. The generation of Mathematics e-module using this software is easy and even interesting. Through this application, it is certainly possible to design an interesting Mathematics e-module for the materials of "Simple Planes" that will be used among the Third-Grade students. At the same time, the Kvisoft Flipbook Maker offers many advantages and one of these advantages is that the Kvisoft Flipbook Maker can be accessed through smartphone or tablet (Darmaji et al., 2019). As a result, the use of the e-module can be interesting for the students since the e-module can be accessed anywhere and at any time (Linda et al., 2018). However, in order to support the learning process, the good e-module is the one that should be combined with the appropriate learning approach or method that suit the needs of the students.

One of the approaches that can be used in designing the Mathematics e-module is the problembased learning (PBL). Problem-based learning (PBL) is one of the constructivism learning theories that facilitate the students to actively solve problems in their learning process (Handayani, 2018). In addition, (Fathurrohman, 2015) states that the problem-based learning (PBL) is an approach that benefits the illstructured and open-ended actual (authentic) problem from the context of the daily life in order to develop the students' skills for solving the problems that have been given and, specifically, to make students think quickly or critically (Purnomo et al., 2019). The use of PBL can make the students to understand the learning materials better and to attain longer retention in comparison to any other method. By using PBL, the teachers are able to make students discover the learning problems independently and continuously. At the same time, through the use of the PBL, the students are expected to be more impressed with the learning process and to find solutions from the given problems (Qudwatullathifah et al., 2019). However, the involvement of the teachers in designing the activities, in keeping the students motivated, and in encouraging the students to take participation in the learning sessions is a challenging task within the implementation of the e-module (Joshi et al., 2020). With regards to the statement, the use of the e-module in the study provides in-depth concept understanding on the cognitive, affective, and psychomotor aspects, which can develop the students' critical thinking and problem-solving skills (Jaenudin et al., 2017).

There are previous studies that have developed the PBL-based learning materials and student worksheets with the combination of mind-mapping for the materials of "Fraction" among the elementary school students; the learning materials and student worksheets are very practical and helpful for both the teachers and the students with easiness of use as the main characteristic (Widialistuti, 2018). In relation to the statement, the use of the ethno-constructivism electronic module with Kvisoft Flipbook Maker in the learning process can be considered fit for use in the learning process of the elementary school (Anandari et al., 2019). The Geometry e-module was previously developed by using the inquiry approach (Suastika \& Wahyuningtyas, 2020). Furthermore, in the previous studies the problem-based learning should be developed with an e-module that benefits other approaches and application. Therefore, as a response to the statement, in the present study the Mathematics e-module for the theme "Simple Planes" will be developed based on the problem-based learning with Kvisoft Flipbook Maker for the Third-Grade students.

\section{Method}

The study was a research and development initiative using the ADDIE Model. The ADDIE development model is a learning design model that has been based on an effective and efficient approach and interactive process; in this model, the evaluation at the end of a stage will deliver to the following stage (Sari et al., 2019). The ADDIE model consists of flexible procedures that assist a researcher in establishing an effective study and these procedures are summarized in the following five stage: (1) Analysis; (2) Design; (3) Development; (4) Implementation; and (5) Evaluation (Nadiyah \& Faaizah, 2015).

In Analysis, the procedures that should be performed were: (1) analyzing the materials; (2) analysing the learning materials; and (3) analysing the students' characteristics. Then, in Design the researcher should design the e-module of Mathematics that would be developed. Next, in Development the researcher should develop the design of the Mathematics e-module. The Mathematics e-module was 
Jurnal Prima Edukasia, 8 (2), 2020 - 202

Dyah Triwahyuningtyas, Ayu Setyo Ningtyas, Sri Rahayu

validated in order to identify the product fitness especially in relation to the implementation of the problem-based learning in the Mathematics e-module. The validity test was performed by consulting the PBL-based Mathematics e-module to the learning material expert and the material expert using the validation sheet. Furthermore, in Implementation the Mathematics e-module was implemented in order to identify the influence of the e-module on the learning quality by means of fitness test (Widyastuti \& Susiana, 2019). Eventually, in Evaluation the researcher should revise the product based on the results of the fitness test, the practicality test, and the effectiveness test so that the product might be implemented in the learning process. It was very important to evaluate every stage that had been performed in order to ensure that the learning objectives had been achieved by using the design and the materials for meeting the students' needs (Aldoobie, 2015).

In conducting the data analysis, the data analysis technique that had been implemented was the qualitative and quantitative data analysis. The descriptive qualitative data analysis was attained from the feedback or the suggestion provided by the experts, while the quantitative data analysis was attained from the completion of the questionnaire that contained the questions related to the PBL-based Mathematics e-module under the materials "Simple Planes" by the validators and the respondents. Last but not the least, the instruments that had been implemented in the study were the e-module validation sheet, the material validation sheet, the teacher questionnaire, the student questionnaire, and the student evaluation sheet.

The Mathematics E-Module for the Theme "Simple Planes" Using the Kvisoft Flipbook Maker Application

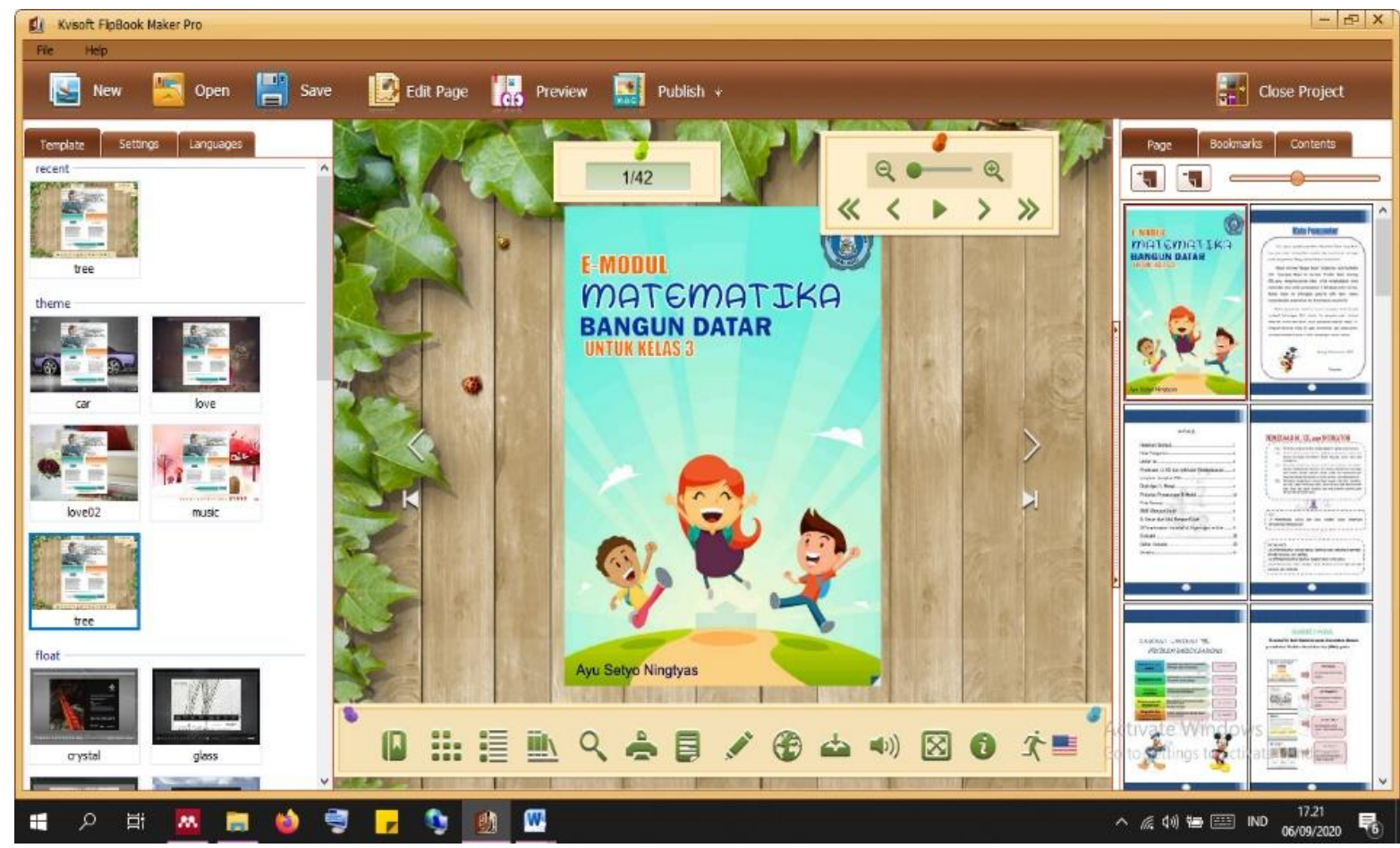

Figure 1. The layout of the Kvisoft Flipbook Maker 4.0 application

The PBL-based Mathematics e-module for the theme "Simple Planes" was developed by using the Kvisoft Flipbook Maker 4.0 application. The Kvisoft Flipbook Maker itself is an application for designing e-book, e-module, e-paper, and e-magazine. This application is not only able to insert texts but also pictures, graphics, sounds, links, and even videos to the worksheet (Hidayatulloh, 2017). Then, the application is used in order to convert the module from the PDF-based files into the electronic module or e-module-based files. The Kvisoft Flipbook Maker application is also easy to use and has many interesting features. In this application, the researcher was able to add pictures, animations, and other features into the e-module so that the students could choose their answers and knew whether their answers were wrong or right. The learning process by use of Kvisfot Flipbook Maker application could be considered as an innovation in the domain of learning materials and this application, therefore, was able to influence the learning process significantly in independently expanding the students' understand- 
Jurnal Prima Edukasia, 8 (2), 2020 - 203

Dyah Triwahyuningtyas, Ayu Setyo Ningtyas, Sri Rahayu

ing toward the concept and the learning (Mulyaningsih \& Saraswati, 2017). The use of the e-module application was added by animations and additional pictures that had been adjusted to the learning process so that the students' attention could be grasped and thus the students could be more active in paying attention to the learning process. The PBL-based Mathematics e-module for the theme "Simple Planes" using the Kvisoft Flipbook Maker could be accessed through the following link: https://bit.ly/EmodulPBL.

\section{Results and Discussions}

The development of the PBL-based Mathematics e-module for the theme "Simple Planes" using the Kvisoft Flipbook Maker with the ADDIE model consists of 5 stages namely: (1) Analysis; (2) Design; (3) Development; (4) Implementation; and (5) Evaluation (Pribadi, 2016). The stage of Analysis consists of the analysis toward the potentials and the problems that the school has (Safitri, 2017). From the results of the analysis toward the learning materials in the school, it is found that the learning material development in the form of e-module is necessary since the existing learning media has been insufficient (Sudarma et al., 2017). The materials that have been analysed are the materials of Mathematics that have been taught under the 2013 Curriculum. In addition, the students' characteristics are also analysed and the analysis, in this regard, includes the students' habits in the mathematical learning process. Then, the stage of Design contains the design of the learning materials that are necessary for the product manufacture (Safitri, 2017). The design of the PBL-based Mathematics e-module for the theme "Simple Planes" using the Kvisoft Flipbook Maker is presented in Table 1.

Table 1. The Design of the E-Module

Information
PBL Stage 1
Orienting the students toward the problems (Let's
Observe!)


Jurnal Prima Edukasia, 8 (2), 2020 - 204

Dyah Triwahyuningtyas, Ayu Setyo Ningtyas, Sri Rahayu

PBL Stage 3

Guiding both the individual and the communal inquiry (Let's Discuss!)

\section{PBL Stage 4}

Developing and Delivering Data (Let’s Share!)

\section{PBL Stage 5}

Analysing and Evaluating the Problem-Solving Process (Let's Draw Conclusions!)

Soal evaluasi
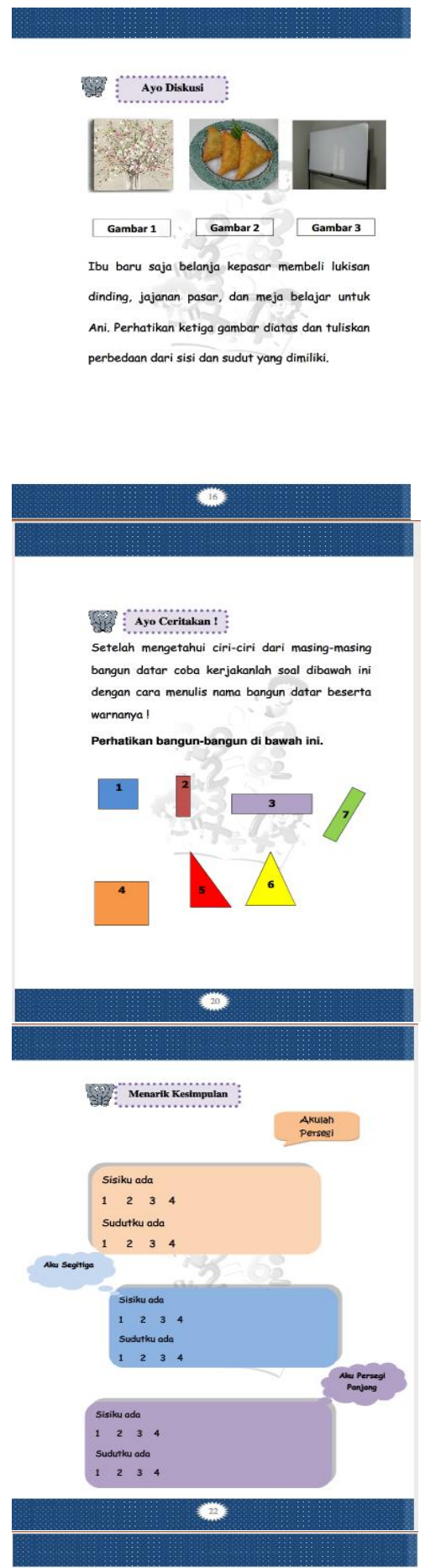

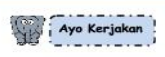

SOAL EVALUASI

1. Keempat pojoknya berbnetuk siku-siku dan keempat sisinya sama panjang adalah sifat bangun ..................

a. persegi panjang

b. persegi

c. setitiga siku-siku

d. segitiga sama sisi

2.

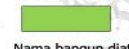

Nama bangun diatas adalah

a. persegi panjang

b. persegi

c. setitiga siku-siku

d. segitiga sama sisi 
Based on the data in Table 1, it is clear that the Mathematics e-module for the theme "Simple Planes" has been designed with adjustment to the PBL and the sequence in the e-module is as follows: (1) Beginning the learning process from a problem; (2) Ensuring that the problem that has been presented is relevant to the actual context; (3) Organizing the learning process around the problems; (4) Delivering the total responsibility to the persons in the learning process; (5) Assigning the small groups; and (6) Improving the students' skills (Fathurrohman, 2015). Within the implementation of the PBL, the students will be directly involved in looking for the solutions to the problem that the teacher has presented and the teacher will only serve as a facilitator (Rahmadani \& Anugraheni, 2017).

Next, the stage of Development elaborates the product manufacture in accordance with the design that has been defined and the product development by attaining the product validation from the experts (Safitri, 2017). The objective of validating the learning materials is to attain the assessment and the suggestion from the team of validators. The validation is performed until the product that has been developed can be considered valid (Linda et al., 2018). Based on the fitness test that the validators, namely the learning materials expert and the material expert, the results of the product fitness are as follows.

Table 2. Results of Assessment from the Teacher Questionnaire and the Student Questionnaire

\begin{tabular}{cc}
\hline Validator & Scores that Had been Attained \\
\hline Learning Materials Expert & $86.98 \%$ \\
Materials Expert & $84.66 \%$ \\
\hline Mean Score & $85.82 \%$ \\
\hline
\end{tabular}

From the assessment results in Table 2, the mean score that all validators have provided is $85.82 \%$ with the category "Fit" (Sugiyono, 2017). The learning process using the PBL-based Mathematics emodule for the theme "Simple Planes" is considered fit for implementation in the mathematical learning process of the Third-Grade students. In sum, based on the results of the validation test and the above elaboration, it can be asserted that the PBL-based Mathematics e-module for the theme "Simple Planes" using the Kvisoft Flipbook Maker is valid or fit for implementation.

Furthermore, the stage of Implementation aims at implementing the learning program using the product that has been developed (Safitri, 2017). The e-module is implemented in the learning process by assigning the e-module to four big groups each of which consists of 8 students. Then, in this stage both the teachers and the students are provided with a questionnaire in order to measure the level of the e-module effectiveness. The results of the practicality test for the PBL-based Mathematics e-module for the theme "Simple Planes" using the Kvisoft Flipbook Maker are attained by distributing the questionnaire to the respondents. The complete results of the practicality test are presented in Table 3.

Table 3. Results of Teacher Questionnaire and Student Questionnaire

\begin{tabular}{cc}
\hline Respondents & Scores that Had been Attained \\
\hline Teacher & 3.74 \\
Student & 3.83 \\
\hline Mean Score & 3.78 \\
\hline
\end{tabular}

The mean score from both the teacher questionnaire and the student questionnaire show that the PBL-based Mathematics e-module for the theme "Simple Planes" is 3.78 with the category "Good." Consequently, it can be asserted that the PBL-based Mathematics e-module for the theme "Simple Planes" is practical in terms of learning materials.

In order to identify the effectiveness of the PBL-based Mathematics e-module that has been developed for the theme "Simple Planes," the researchers should analyse the learning test results of the students. The students will be considered "Passed" if the results of their learning test have met or exceeded the passing grade criterion, which is adjusted to the existing passing grade namely $>70.00$. The mean score of the test results that have been attained after the PBL-based Mathematics e-module for the theme "Simple Planes" is 90.47. As a result, the effectiveness of the PBL-based Mathematics e-module for the theme "Simple Planes" belongs to the "Good" category. Therefore, departing from the above elaboration, it can be considered that the PBL-based Mathematics e-module for the theme "Simple Planes" using the Kvisoft Flipbook Maker is fit, practical, and effective for implementation in the learning process of the Third-Grade students. 
Jurnal Prima Edukasia, 8 (2), 2020 - 206

Dyah Triwahyuningtyas, Ayu Setyo Ningtyas, Sri Rahayu

Eventually, the stage of Evaluation contains the evaluation toward the e-module that has been developed (Sudarma et al., 2017). In this stage, there are revisions toward the PBL-based Mathematics e-module that has been developed and implemented for the theme "Simple Planes" based on the results of the validation test, the teacher questionnaire, and the student questionnaire. In this stage, the evaluation is performed by checking the conformity of all aspects within the e-module with reference to the results of the quantitative data analysis and the suggestions provided in both questionnaires (Sudarma et al., 2017). However, since the e-module has met all of the assigned criteria, further revisions are not necessary to pursue. The PBL-based Mathematics e-module for the theme "Simple Planes" using the Kvisoft Flipbook Maker can be accessed through the following link: https://bit.ly/EmodulPBL.

Based on the results of the analysis toward the criteria of the learning e-module that have been met, it can be concluded that the PBL-based Mathematics e-module for the theme "Simple Planes" have already met the three test criteria for a learning e-module namely: (1) fit; (2) practical; and (3) effective. Therefore, the PBL-based Mathematics e-module for the theme "Simple Planes" can be used as a supplementation learning material for the teaching-learning process.

\section{Conclusions}

Based on the results of the learning materials development that has been performed, it can be concluded that the PBL-based Mathematics e-module for the theme "Simple Planes" are valid for implementation. The validity is proven by the validators, consisting of the learning materials expert and the material expert, with their mean score $85.82 \%$. Therefore, the validity of the e-module that has been developed belongs to the "Good" category. In addition, the mean score of the practicality test for the emodule that has been developed is 3.78 with the "Good" category. Furthermore, the results of the effectiveness test for the e-module that has been developed is 90.47 with the "Good" category because the mean score of the students' test results already pass the minimum criteria or higher than 70.00 .

It is expected that the PBL-based Mathematics e-module for the theme "Simple Planes" using the Kvisoft Flipbook can serve as alternative learning materials. In addition, it is also expected that the PBLbased Mathematics e-module for the theme "Simple Planes" can facilitate the teachers in increasing the students' interest when they learn Mathematics, provide new insights to the students, and serve as the source of references for the sustainable study.

\section{References}

Aldoobie, N. (2015). ADDIE model analysis phase. American International Journal of Contemporary Research, 5(6), 68-72. https://doi.org/10.13140/2.1.4687.6169

Anandari, Q. S., Kurniawati, E. F., Marliana, M., Piyana, S. O., Melinda, L. G., Meidiawati, R., \& Fajar, M. R. (2019). Development of electronic module: Student learning motivation using the ethnoconstructivism-based. Jurnal Pedagogik, 6(2), 416-436. https://doi.org/10.33650/pjp.v6i2.584

Anwas, O. M. (2014). Audiobook: Media pembelajaran masyarakat modern. Jurnal Teknodik, 18(1). https://doi.org/10.32550/teknodik.v18i1.111

Budiman, H. (2017). Peran teknologi informasi dan komunikasi dalam pendidikan. Al-Tadzkiyyah: Jurnal Pendidikan Islam, 8(1), 31. https://doi.org/10.24042/atjpi.v8i1.2095

Darmaji, D., Astalini, A., Kurniawan, D. A., Parasdila, H., Irdianti, I., Susbiyanto, S., Kuswanto, K., \& Ikhlas, M. (2019). E-module based problem solving in basic physics practicum for science process skills. International Journal of Online and Biomedical Engineering (IJOE), 15(15), 4. https://doi.org/10.3991/ijoe.v15i15.10942

Divayana, D. G. H., Suyasa, P. W. A., Ariawan, I. P. W., Mahendra, I. W. E., \& Sugiharni, G. A. D. (2019). The design of digital book content for assessment and evaluation courses by adopting superitem concept based on Kvisoft Flipbook Maker in era of industry 4.0. Journal of Physics: Conference Series, 1165, 012020. https://doi.org/10.1088/1742-6596/1165/1/012020

Fathurrohman, M. (2015). Model-model pembelajaran inovatif (N. Hidayat (ed.)). Ar-Ruzz Media.

Haeruman, L. D., Rahayu, W., \& Ambarwati, L. (2017). Pengaruh model discovery learning terhadap peningkatan kemampuan berpikir kritis matematis dan self-confidence ditinjau dari kemampuan 
Jurnal Prima Edukasia, 8 (2), 2020 - 207

Dyah Triwahyuningtyas, Ayu Setyo Ningtyas, Sri Rahayu

awal matematis siswa SMA di Bogor Timur. Jurnal Penelitian Dan Pembelajaran Matematika, 10(2). https://doi.org/10.30870/jppm.v10i2.2040

Handayani, M. (2018). Developing thematic-integrative learning module with problem-based learning model for elementary school students. Jurnal Prima Edukasia, 6(2), 166-176. https://doi.org/10.21831/jpe.v6i2.14288

Hidayatulloh, M. S. (2017). Pengembangan e-modul matematika berbasis problem based learning berbantuan geogebra pada materi bilangan bulat. AKSIOMA, 7(2), 24. https://doi.org/10.26877/aks.v7i2.1416

Hutama, F. S. (2016). Pengembangan bahan ajar IPS berbasis nilai budaya using untuk siswa sekolah dasar. JPI (Jurnal Pendidikan Indonesia), 5(2), 113. https://doi.org/10.23887/jpiundiksha.v5i2.8359

Irma, I., Arsyad, A., Syafe'i, S., \& Bahraeni, B. (2019). Pengembangan bahan ajar teknologi pembelajaran berbasis web-blog pada mahasiswa Fakultas Tarbiyah dan Keguruan Universitas Islam Negeri Alauddin Makassar. Jurnal Inspiratif Pendidikan, 8(2). https://doi.org/10.24252/ip.v8i2.7888

Jaenudin, A., Baedhowi, P., \& Murwaningsih, T. (2017). The effectiveness of the e-module of economics learning on problem-based learning used to improve students' learning outcomes. Proceedings of the International Conference on Teacher Training and Education 2017 (ICTTE 2017). https://doi.org/10.2991/ictte-17.2017.32

Joshi, A., Desai, P., \& Tewari, P. (2020). Learning analytics framework for measuring students' performance and teachers' involvement through problem based learning in engineering education. Procedia Computer Science, 172, 954-959.

https://doi.org/10.1016/j.procs.2020.05.138

Linda, R., Herdini, H., S, I. S., \& Putra, T. P. (2018). Interactive E-module development through chemistry magazine on Kvisoft Flipbook Maker application for chemistry learning in second semester at second grade senior high school. Journal of Science Learning, 2(1), 21. https://doi.org/10.17509/jsl.v2i1.12933

Mulyaningsih, N. N., \& Saraswati, D. L. (2017). Penerapan media pembelajaran digital book dengan Kvisoft Flipbook Maker. JPF Jurnal Pendidikan Fisika, 5(1). https://doi.org/10.24127/jpf.v5i1.741

Munthe, E. A., Silaban, S., \& Muchtar, Z. (2019). Discovery learning based e-module on protein material development. Proceedings of the 4th Annual International Seminar on Transformative Education and Educational Leadership (AISTEEL 2019). https://doi.org/10.2991/aisteel19.2019.137

Nadiyah, R. S., \& Faaizah, S. (2015). The development of online project based collaborative learning using ADDIE Model. Procedia - Social and Behavioral Sciences, 195, 1803-1812. https://doi.org/10.1016/j.sbspro.2015.06.392

Nur'aini, I. L., Harahap, E., Badruzzaman, F. H., \& Darmawan, D. (2017). Pembelajaran matematika geometri secara realistis dengan geogebra. Matematika, 16(2), 1-6. https://doi.org/10.29313/jmtm.v16i2.3900

Pribadi, B. A. (2016). Desain dan pengembangan program pelatihan berbasis kompetensi implementasi model ADDIE. Kencana.

Purnomo, H., Santosa, B., \& Tentama, F. (2019). Implementation of problem-based learning and group investigation (PBL go-in) to improve vocational students' competence. Journal of Vocational Education Studies, 2(1), 47. https://doi.org/10.12928/joves.v2i1.750

Qudwatullathifah, R. N., Suyitno, H., \& Ridlo, S. (2019). Students' problem solving ability based on the fraction concept mastery in the PBL model. Journal of Primary Education, 8(8), 207-214. https://doi.org/10.15294/JPE.V10I2.34451

Rahmadani, N., \& Anugraheni, I. (2017). Peningkatan aktivitas belajar matematika melalui pendekatan problem based learning bagi siswa kelas 4 SD. Scholaria: Jurnal Pendidikan Dan Kebudayaan, 7(3), 241. https://doi.org/10.24246/j.scholaria.2017.v7.i3.p241-250 
Jurnal Prima Edukasia, 8 (2), 2020 - 208

Dyah Triwahyuningtyas, Ayu Setyo Ningtyas, Sri Rahayu

Rohman, A. N., Karlimah, K., \& Mulyadiprana, A. (2017). Analisis kemampuan komunikasi matematis siswa kelas III sekolah dasar tentang materi unsur dan sifat bangun datar sederhana. Jurnal PEDADIDAKTIKA: Jurnal Ilmiah Pendidikan Guru Sekolah Dasar, 4(2). https://ejournal.upi.edu/index.php/pedadidaktika/article/view/7128

Safitri, I. (2017). Pengembangan e-module dengan pendekatan pembelajaran matematika realistik berbantuan flipbook maker pada materi bangun ruang sisi datar kelas VIII SMP. AKSIOMA, 6(2), 1. https://doi.org/10.26877/aks.v6i2.1397

Santosa, A. S. E., Santyadiputra, G. S., \& Divayana, D. G. H. (2017). Pengembangan e-modul berbasis model pembelajaran problem based learning pada Mata Pelajaran Administrasi Jaringan kelas XII Teknik Komputer dan Jaringan di SMK TI Bali Global Singaraja. Kumpulan Artikel Mahasiswa Pendidikan Teknik Informatika (KARMAPATI), 6(1), 62. https://doi.org/10.23887/karmapati.v6i1.9269

Sari, Y. P., Sunaryo, Serevina, V., \& Astra, I. M. (2019). Developing E-Module for fluids based on problem-based learning (PBL) for senior high school students. Journal of Physics: Conference Series, 1185, 012052. https://doi.org/10.1088/1742-6596/1185/1/012052

Setiawan, R., Mardapi, D., Pratama, A., \& Ramadan, S. (2019). Efektivitas blended learning dalam inovasi pendidikan era industri 4.0 pada mata kuliah teori tes klasik. Jurnal Inovasi Teknologi Pendidikan. https://doi.org/10.21831/jitp.v6i2.27259

Sriwahyuni, I., Risdianto, E., \& Johan, H. (2019). Pengembangan bahan ajar elektronik menggunakan flip PDF professional pada materi alat-alat optik di SMA. Jurnal Kumparan Fisika, 2(3), 145152. https://doi.org/10.33369/jkf.2.3.145-152

Suastika, I. K., \& Wahyuningtyas, D. T. (2020). Inquiry-based E-module for Geometry Learning Subject. Universal Journal of Educational Research, 8(1), 243-248. https://doi.org/10.13189/ujer.2020.080130

Sudarma, I. G., Arthana, I. K. R., \& Sindu, I. G. P. (2017). Pengembangan e-modul dengan model problem based learning mata pelajaran pemrograman dasar kelas XI teknik komputer dan jaringan di SMK Negeri 3 Singaraja. Kumpulan Artikel Mahasiswa Pendidikan Teknik Informatika (KARMAPATI), 6(1), 239. https://doi.org/10.23887/karmapati.v6i1.9702

Sugiyono, S. (2017). Metode penelitian pendidikan (Pendekatan kuantitatif, kualitatif, dan $R \& D$ ). Alfabeta.

Supriadi, N. (2015). Mengembangkan kemampuan koneksi matematis melalui buku ajar elektronik interaktif (BAEI) yang terintegrasi nilai-nilai keislaman. Al-Jabar: Jurnal Pendidikan Matematika, 6(1), 63-74. https://doi.org/10.24042/ajpm.v6i1.51

Suwardi, S., Firmiana, M. E., \& Rohayati, R. (2016). Pengaruh penggunaan alat peraga terhadap hasil pembelajaran matematika pada anak usia dini. Jurnal Al-Azhar Indonesia Seri Humaniora, 2(4), 297. https://doi.org/10.36722/sh.v2i4.177

Widialistuti, R. (2018). Praktikalitas pengembangan modul dan LKS dengan menggunakan problem based learning dan perpaduan mind mapping pada materi pecahan kelas IV sekolah dasar di Kecamatan Sijunjung. Unes Journal of Education Scienties, 2(2), 090. https://doi.org/10.31933/ujes.2.2.090-097.2018

Widyastuti, E., \& Susiana. (2019). Using the ADDIE model to develop learning material for actuarial mathematics. Journal of Physics: Conference Series, 1188, 012052. https://doi.org/10.1088/1742-6596/1188/1/012052

Winatha, K. R., \& Abubakar, M. M. (2018). The usage effectivity of project-based interactive emodule in improving students' achievement. Jurnal Pendidikan Teknologi Dan Kejuruan, 24(2), 198-202. https://doi.org/10.21831/jptk.v24i2.20001 